\title{
Brazilian Food Plants Registered in Historical Documents
}

\author{
Maria Franco Trindade Medeiros
}

\section{Contents}

1 Cultural Memory of Cooking in Brazil..................................... 117

2 Food Species of Brazilian Flora Registered in Past Documents....................... 121

3 Brief Words of Conclusion................................................. 124

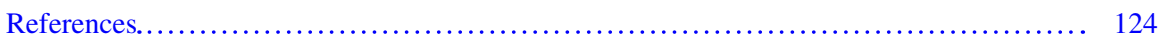

\section{Cultural Memory of Cooking in Brazil}

The principle of the process of growing plant species may involve several myths and legends in different human cultures. We have the community with its mythological traditions around the origins of indigenous and local cultures, and, at the same time, we deal with the practice of biological exchange through the circulation of botanical species resulting from intercontinental travels carried out by numerous historical characters of human civilization.

If we consider only two historical landmarks, we could affirm that, since the thirteenth century, we find reports from Marco Polo about his travels and descriptions of an island where there were pepper, nutmeg, as well as other spices that can still be found in the present day around the world (Pereira 1922; Balick and Cox 1996), and when we analyze the voyages of the discovery of the Americas, we can also situate over time some facts that marked the way in which humanity was identifying the question of how to feed, what would be the sources of proteins, vitamins, and minerals. Nevertheless, certainly many exchanges between different ethnicities had already occurred in periods prior to Marco Polo's existence and action.

Specifically, talking about the Brazilian territory, it encompasses multiple community experiences woven over the centuries of coexistence between its original peoples and other inhabitants from different regions of origins. Each of its five regions (South, Southeast, Northeast, North, and Midwest) contributes to a specific way in the feeding of Brazilians. From a thorough, detailed research of local

M. F. T. Medeiros ( $\square)$

Laboratório Interativo em Etnobotânica (LINE), Departamento de Botânica, Museu Nacional, Universidade Federal do Rio de Janeiro, Rio de Janeiro, RJ, Brazil 
traditions related to food and the search for family recipes, we can perceive how Brazilian cuisine is varied and rich in flavors.

With ingredients brought from other parts of the world and with the very ones of each Brazilian region, a history of local cuisine and, in a larger context, a national food identity were forged. It is a history that was woven with the recombination of ingredients from Europe, where eggs, milk, and wheat flour (Triticum aestivum L.) came from, along with what Brazil offered from food species such as corn (Zea mays L.), sugar from sugar cane (Saccharum officinarum L.) fields, cassava (Manihot esculenta Crantz) flour, and countless fruits considered exotic. Thus, in this national cuisine, the dishes were commonly composed of a mixture of the creativity of the people dedicated to the preparation of food that elaborated the arrangement of preparations from ingredients not only from Europe and territories with which they maintained commercial relations, such as the Middle East and the Far East, as well as with those of indigenous origin but also composed the culinary adaptations those typical ingredients of the eating habits of the African peoples.

The time of the discovery of Brazil and the following centuries also comprised the period of food exchanges that came and went along the routes of the great navigations (Medeiros 2018). Thus, the cashew of Brazil went to Goa, as well as to Africa the cassava, corn, and peanuts (Arachis hypogaea L.). From Africa to Brazil came, for example, okra (Hibiscus esculentus L.), yams (Dioscorea alata L.), fennel (Pimpinella anisum L.), yellow ginger (Zingiber officinale Roscoe), and watermelons (Citrullus lanatus (Thumb.) Mansf.) (Costa 1983; Baker 1968; Balick and Cox 1996).

In one way or another, it occurred that African food culture has imprinted peculiar traits that are present today. In regions such as Salvador and throughout the region of the Recôncavo Baiano (Bahian region located in northeastern Brazil), this influence was affirmed in the tasting appreciation of three ingredients considered basic for this cuisine that brings strong African influence. These ingredients are coconut milk (Cocos nucifera L.), palm oil (Elaeis guineensis Jacq.) and pepper (Capsicum spp., Piper spp. and Pimenta spp.). In the work Etiópia Oriental (Eastern Ethiopia), published in 1609, in the city of Évora (Portugal), Friar João dos Santos described the process of obtaining coconut milk saying that it was extracted from fresh coconut, grated and well washed in two or three waters, and squeezed between the hands (Santos 1999 [1609]). In this way the coconut was dry and the water in which it was washed was thick as cow's milk.

Let us take a more detailed look at some of the regions that compound the Brazilian territory in relation to their historical traditions on the feeding modes of local populations.

Vestiges of the food memory of the northeast region can be found in works that Gilberto Freyre (1933) left us. The way of feeding was registered by this sociologist, which leads us to the understanding that in the past and still in the present days the cuisine of this region combines extremes in its menu. So, this means that the most regional ingredients alongside the international ones are served as elements of the northeastern diet in both the more rustic and refined foods. 
In a report about José dos Santos Torres about the menu of his hotel in Pernambuco (northeastern Brazil), Freyre points out that in this space were served various Brazilian and European delicacies. The folklorist Luís da Camara Cascudo (1983) through away the interior of this region and observed the menu served in each moment of the day, as did the doctor Antônio da Silva Mello (1946, 1964) who travelled through the interior of the state of Pernambuco during the 1940s for his researches on nutrition.

The brief stay of the French in Maranhão (northeastern Brazil) during the seventeenth century could be registered in detail by the Capuchin priest Claude D'Abbeville, in his work História da Missão dos padres Capuchinhos na Ilha do Maranhão e Terras Circunvizinhas (History of the Mission of the capuchin fathers on the Island of Maranhão and Surrounding Lands), of 1614 (D'Abbeville 1874 [1614]). Father D'Abbeville spent only 4 months in Brazil and left us the report on the tasting that had countless fruits and roots of the region. In Maranhão, fruits such as bacuri (Platonia insignis Mart.), jacama (Annona muricata L.), cupuaçu (Theobroma grandiflorum (Willd. ex Spreng.) K. Schum.), and jenipapo (Genipa americana L.) appear as dessert fruits on the menus. Whether in natura, or in form of ice cream, candied sweets, candy in syrup or compotes, to this day these culinary finds of D'Abbeville are of popular taste, thus demonstrating that certain "finds" are "eternal".

In northern Brazil, indigenous influence was preponderant. In this region, there is a living past, which is updated in the execution of dishes such as pato no tucupi (duck made in tucupi, a broth made from manioc root fermentation), açaí wines (Euterpe oleracea Mart.), and tacacá (tacacá, a mixture of manioc gum and tucupi broth added with seasonings, aromatic herbs, and dry shrimp). The culinary base of Pará (state of this region) was created by indigenous in remote times. Besides, food products from manioc, such as pirões (fish porridge) and beijus (manioc flour), açaí, piquiá (Caryocar brasiliense Cambess.), pupunha (Bactris gasipaes Kunth), and buriti (Mauritia flexuosa Mart.) integrate the traditional menu of this region. In the Amazon, another state of this same region, dozens of native fruits are consumed, and guarana (Paullinia cupana Kunth) is highlighted as a drink that prolongs life.

Regarding the southeastern Brazil, there are numerous annotations on the menus of the nineteenth century, time when the naturalists August saint-Hilaire and Johann Pohl were in Brazil. Being in the state of Minas Gerais, these naturalists left registered experiences about behaviors and domestic habits of families in this region. It was common practice to have a separate menu for men, women, and children. The customs of eating black beans (Phaseolus vulgaris L.) with corn flour for lunch and vegetables cooked at supper, commonly kale (Brassica oleracea var. viridis L.), chicory (Cichorium endivia L.), okra, or almeirão (Cichorium intybus L. var. intybus) are described (Saint-Hilaire 1974 [1822]). There are some specialties that remain almost secret. These are stored in the scope of the regional, as is the case of sweet buriti or thick syrup of araçá (Psidium guineense Sw.) and piquiá, and in Espírito Santo (also southeastern state), the use of annatto (Bixa orellana L.) seeds in the preparation of the moqueca capixaba (dish made of tomato sauce, annatto, fish, and seasonings). 
It is noteworthy that many of the families of Portuguese origin lent their own names, both family and sugar mill, to baptize a special recipe as a way to honor these people. An example of this tradition is the Souza Leão cake, dough made of manioc and coconut milk, as well as the cakes Cavalcanti, Tia Sinhá, and Fonseca Ramos.

With an extraordinary floristic richness that inspired and gave way to the local culinary creativity of the most varied environments, many recipes have certainly been lost throughout history. The social condition that the mucamas (black women servants of the white ladies) and sinhás (white ladies) assumed was to be illiterate, and their recipes had as a major form of conservation the immaterial memory and the transmission of their culinary knowledge by the exercise of orality. We believe that this issue constitutes one of the difficulties of working with the theme of food plants of ancient use, because the research of old recipes is compromised to the extent that many of them were not been written. Being usually an activity related to making feminine, the act of cooking was conditioned on women, both of the most humble condition and the most noble, such as the baronesses and viscountesses of the Empire, who were often illiterate.

Foods created over the centuries of creativity in the face of countless ingredients have gained the taste of the Brazilian population, overcoming taboos and prejudices. Wanting to please the palate was a creative effort of generations of cooks who transcended centuries of dedication to the art of dietetics. In fact, we commented only on the actuations of women, but men also integrated this action in the preparation of foods. As Freyre (1933) present us, among the slaves in the domestic service of the casas-grandes (the large houses where lived the lords and their families), those who dedicated themselves to the kitchen were within this extreme culinary specialization. Generally, two or three individuals were chosen for the kitchen services. Alongside women, blacks considered incapable of raw service could also be reserved for this service. The note of Freyre about newspaper advertisements from the time of slavery in Brazil that gave visibility to the escape of these black people who worked in the kitchen is interesting. These notes specified that in the act of escape, these blacks were dirty because they were cooks.

Thus, if we can trace a more general panorama, disregarding the infinite specificities of each corner of the Brazilian territory and what was able to mix and create each community experience in its particular living space, this would be the most common scenario of this space so used and so central in the past life of the Colonial and Imperial period of Brazil, that is, the kitchen. Sinhás and black people dedicated to the preparation and creation of dishes, sweets, and preserves with fruits and roots of the earth, so amazing in their new flavor, have been gaining the taste of the palate and remain present until the present day in national cuisine. 


\section{Food Species of Brazilian Flora Registered in Past Documents}

The food plants and their cultivation, in addition to their multiple uses, can be pointed out as having been one of the first measures thought by those who came to the Brazilian territory with the mission of populating it from the conquest undertaken by the Lusitanians. Since the founding of Colonial Brazil, the newly arrived settlers in the new territory have taken care of securing items for their most pressing survival needs. In this sense, the actions have moved towards the beginning of agriculture and, further forward in history, to the development of some profitable industries. Thus, in this process, the cultivation of cereals and vegetables were the first to be implemented. Then, the fruit species and grasses for the forage of animals gained space in the productive force. On the other hand, the plant species that supplied other genera began to be cultivated later.

In 1551, there is the register made by the Father Manuel da Nóbrega of Pernambuco (northeastern Brazil) that there was the culture of several plants brought from the metropolis. Ciders (Melissa officinalis L.), vines (Vitis vinifera L.), orange trees (Citrus x sinensis (L.) Osbeck), lemon trees (Citrus x aurantiifolia (Christm.) Swingle), and figs (Ficus carica L.) were mentioned. Father Nóbrega took care to mention that these cultivars were as good as those in Europe and that they were very productive (Nóbrega 1955 [1551]).

Another register that tell us about this dynamic of food cultivars in the history of occupation of the Brazilian territory is that left by Gândavo, dated 1576. In this document he refers to banana (Musa paradisiaca L.) from the Island of São Tomé, ananas (Ananas comosus (L.) Merr. var. comosus), melons (Cucumis melo L.), cucumbers (Cucumis sativus L.), pomegranates (Punica granatum L.), and figs of many varieties, as well as ciders, lemons, and oranges.

In the Jesuit College located in the city of Olinda, in the former Captaincy of Pernambuco, located in the northeastern region of Brazil, there was the cultivation of several food species, according to a mention made by Father Fernão Cardim (1925 [1584]). On a visit to the College of Olinda in1584, Father Fernão could see that in the Jesuits' backyard there were vines, fig trees, orange trees, melons, cucumbers, and pomegranates. The following year, in 1585, Father José de Anchieta (1933 [1585]) when writing about this same College of Jesuit Fathers still mentions the many coconut trees that existed in that place.

In 1587, in the work Tratado Descritivo do Brasil (Descriptive Treaty of Brazil), Gabriel Soares de Sousa also emphasizes the food plants that he found in Brazil. In his register he speaks about the cultivation of several species, being these lime (Citrus limettioides Tanaka), French lemon (Citrus x limonia (L.) Osbeck), and Galician lemon, rice (Oryza sativa L.), and yams from Cape Verde and São Tomé, and others such as watermelon, pumpkin (Cucurbita moschata Duchesne), mustard (Brassica spp.), turnip (Brassica rapa L.), cabbage, lettuce (Lactuca sativa L.), coriander (Coriandrum sativum L.), dill (Anethum graveolens L.), parsley (Petroselinum spp.), mint (Mentha spp.), chives (Allium schoenoprasum L.), 
aubergine (Solanum melongena L.), alfavaca (Ocimum spp.), bredo (Amaranthus spp.), chicory, carrot (Daucus carota L.), spinach (Tetragonia tetragonioides (Pall.) Kuntze), and basil (Ocimum spp.) (Sousa 1971 [1587]).

Resuming the coconut tree culture, it is noticed that it has gained an expressive development for its variety of uses, and its spread throughout the Brazilian territory was already extensive in 1618, as described in Diálogos da Grandeza do Brasil, (Dialogues of the Greatness of Brazil) of Brandão (2010 [1618]). Before the Dutch invasion in northeastern Brazil, in História da Guerra de Pernambuco (History of the Pernambuco War), Santiago (1984 [1634]) describes a landscape full of coconut trees and says that there was no residence in which there was at least some individuals of this specie in the city of Olinda, in the former Captaincy of Pernambuco. $\mathrm{He}$ also adds that the presence of coconut trees in the backyards of the houses of the city of Olinda gave a special characteristic to that landscape.

It is also been cultivated since the sixteenth century in Brazil the ginger, that was brought from the Island of São Tomé. Its production gained space in Brazilian territory, which contributed to its export in 1575. Thus, as this ginger produced in Brazil was considered of better quality than that of India, it gained the preference of its consumers. For this reason, its culture was forbidden so that trade with the East would not be harmed (Costa 1983). Only on April 24, 1642, this prohibition was repealed and a new provision was enacted, allowing Brazilian people the culture of ginger. This permission was valid for the cultivation of the species on land that was considered unsuitable for sugarcane cultivation. In addition, it had been stipulated that its export would be made available, by the paying the competent duties. Another provision issued on April 10, 1671, changed this scenario. At least in the Captaincy of Pernambuco, the cultivation of ginger was recommended, and its export was allowed without the collection of taxes.

Years later, on March 30,1678, a royal letter addressed to the governor of Pernambuco communicated that he had ordered the Viceroy of India to consign fruit trees to this captaincy and to the kingdom, for the usefulness that could favor this state, as for the whole Kingdom of Portugal. Later, already on May 20, 1862, there was a new communication from the king issued to the Viceroy with similar orders, and he also ordered that when ships with cargo of useful plants arrived at the captaincy of Pernambuco, the governor should have to look for these plants, and plant them in accordance with India's instructions.

Reaching the years of 1800 , on July 7, 1810, the pepper culture of India was recommended, as well as that of other exotic or indigenous plants, as the native species of Brazil were called (Costa 1983). It meant that native plants were now considered for planting. The intention was that uncultivated species, native to Brazil, could constitute new materials suitable for consumption, in addition to becoming export items and moving trade due to their various applications. The cultivators were guaranteed exemption from customs fees by a period of 10 years, awards, honorary medals, and also, exemption from service and recruitment in the military sector. These measures were reiterated in the following year of 1811 by new provisions which were issued in this same sense as the provisions of 1810 . 
These measures taken point out very clearly how there was a movement of stimulus and protection to the culture of new species that were promising, and, thus, like those mentioned recently, there are many other measures that were issued with the same objective. These documents provide information about the transformation of the landscape of phytogeographic domains existing in Brazil, although they refer more massively to the economic movement determined by the Metropolis to its Colony. The central economies revolved around species not yet mentioned, such as coffee (Coffea arabica L.), cotton (Gossypium spp.), and sugarcane (Dean 1996). Although there was this centrality in cultivars interesting to the economy, so many other cultivars considered to be peripheral also existed. These peripheral economies were managed by populations that were right on the periphery of the colonial system. These were fields of cultivation for subsistence that were configurated as being relevant to the survival of mestizos, riverside, quilombolas (black slaves who formed community enclaves reactionaries to the slavery system), caiçaras (communities composed of indigenous peoples, Portuguese settlers, and African slaves who supported themselves from agriculture, small-scale fishing and plant extractivism), and many other Brazilian community formations.

The native species managed by these populations served for the most different utilities, such as for medicine or as a source of food. Taking as an example the secondary forests on the landscape of the Atlantic Forest, we can find nowadays introduced exotic species and managed native species (Oliveira and Silva 2011). These are traces of the memory of past local culture. Among these species, we can cite the jack (Artocarpus heterophyllus Lam.), whose culture dates back to ancient times, which can be inferred by the denomination of mills and villages known by this term since many years ago. Another species that we can illustrate here in this incorporation into the floristic composition of a secondary forest would be the coffee.

Among the native species that were managed and that nowadays can be found in secondary forests of the Atlantic Forest, these compound a diverse set including pioneers, initial and late secondaries of ecological succession present in areas equivalent to abandoned swideens (Oliveira and Silva 2011). Considering the plasticity of management practices and the differentiated objectives of each of these practices in terms of production and conservation, these may lead to the incorporation or populational prevalence of certain species in the forest environment, depending on the conditions of the environment, cultural, and economic traits of the locality (Noble and Dirzo 1997). A group of plant resources that can receive greater attention from management practices in the forest environment is that of so-called intentionally managed species, which includes native fruits. This set of species has been gaining over time priority in planting on the edges and within the forests. Among these are the jabuticaba (Myrciaria cauliflora (Mart.) O. Berg.), the chestnut tree (Bombacopsis glabra (Pasq.) Robyns), the cambucá (Plinia edulis (Vell.) Sobral), and the cajá-mirim (Spondias mombin L.) (Oliveira and Silva 2011).

Thus, the use of food species by past populations passed through a culture within forest areas. Registers in different supports in this regard are not usual to be found, but the work with oral history can provide more information about these past management practices. What we can perceive through the presence of species such as 
those mentioned is that there is a valuation of the forest environment in past periods, including the intentional planting of plant species elected as being important for the experience of an ancient community. The landscape then gains contours from the human action carried out in the past and that, also, expands in time and continues to bring interferences on ecological and food patterns nowadays. Thus, in the constitution of a list of species suitable for the ingestion, there is an identity character that is configured as being historical.

\section{Brief Words of Conclusion}

In the history of the use of food plant resources, historical documentation reveals to us with greater intensity data related to the dominant center of the Brazilian colonial economy. The relations of the human population present in the Brazilian territory that were on the fringes, on the periphery of the central economy, left few documented reports. The historiography of the landscape of the Brazilian phytogeographical domains deserves further investigation in each of its representativeness. What we have found so far is a narrative that highlights the bias of actors and cultures of species that played a central role in the economy.

However, we can point out as key species for the future of human food security the acceptance of food plants that transcend centuries through collective dietary memory.

In addition to this primary need, we leave the indication that the behavior is what could be configured as the key to a balanced relation with flora (and nature in its entirety) in order to consider it not only as a source of consumption, but rather a fundamental part of the experiential constitution of humanity.

\section{References}

José de Anchieta A (1933 [1585]) Cartas, informações, fragmentos históricos e sermões do Padre Joseph de Anchieta, S.J. (1554-1591). Civilização Brasileira S.A., Rio de Janeiro

Baker HG (1968) Las plantas y la civilización. Herrero Hermanos Sucessores S.A, Ciudad de México

Balick MJ, Cox PA (1996) Plant, people, and culture: the science of etnobotany. Scientific American, New York

Brandão AF (2010 [1618]) Diálogos das grandezas do Brasil. Senado Federal, Conselho Editorial, Brasília

Cardim Pe F (1925 [1584]) Tratados da terra e gente do Brasil. J. Leite \& Cia, Rio de Janeiro

Cascudo Luís da C (1983) História da alimentação no Brasil. Itatiaia, Belo horizonte; Editora da Universidade de São Paulo, São Paulo

da Costa FAP (1983) Anais Pernambucanos. FUNDARPE, Recife

D'Abbeville Pe C (1874 [1614]) História da Missão dos Padres Capuchinhos na Ilha do Maranhão e suas Circumvisinhanças. Typ. do Frias, Maranhão 
Dean W (1996) A ferro e fogo. A história e a devastação da Mata Atlântica brasileira. Companhia das Letras, São Paulo

Freyre G (1933) Casa-Grande e Senzala. Maia \& Schmidt, Rio de Janeiro

de Gândavo PM (1576) Historia da província Santa Cruz a que vulgarmente chamamos Brasil. Officina de Antonio Gonsaluez, Lisboa

Medeiros MFT (2018) Medicinal plants and state policy in South America: the case of colonial Brazil. In: Albuquerque UP, Patil U, Mathe A (orgs.) Medicinal and aromatic plants of south America - Brazil. Springer, Dordrecht, 71-80

da Silva Mello A (1946) Alimentação no Brasil - problemas e soluções. Edições Cruzeiro, São Paulo

da Silva Mello A (1964) Nordeste brasileiro. Estudos e impressões, José Olympio, São Paulo

Noble IR, Dirzo R (1997) Forest as human-dominated ecosystems. Science 277:522-525

da Nóbrega Pe M (1955 [1551]) Cartas do Brasil e mais escritos do Pe. Manuel da Nóbrega (Opera Omnia). Ed. Serafim Leite. Universidade, Coimbra

Oliveira RR, Silva IM (2011) História da paisagem e paisagens sem história: espécies exóticas e nativas manejadas na Mata Atlântica. In: Peixoto AL Silva IM (orgs.) Saberes e usos de plantas: legados de atividades humanas no Rio de Janeiro. Ed. PUC-Rio, Rio de Janeiro, p 69-92

Pereira FE (ed) (1922) O livro de Marco Paulo (1502). Ed. Nacional, Lisboa

de Saint-Hilaire A (1974 [1822]) Segunda viagem do Rio de Janeiro a Minas Gerais e a São Paulo. Itatiaia, Belo Horizonte; Editora da USP, São Paulo

Santiago DL (1984 [1634]) História da guerra de Pernambuco. FUNDARPE, Recife; Diretoria de Assuntos Culturais

dos Santos Frei J (1999 [1609]) Etiópia Oriental. CNCDP, Lisboa

de Sousa GS (1971 [1587]) Tratado descritivo do Brasil em 1587. C.E.N., São Paulo 